\title{
CHURCHES BY DALMATIAN ARCHITECTS OF THE SEVENTEENTH AND EIGHTEENTH CENTURIES
}

\author{
Vladimir Marković
}

\author{
V. Marković \\ Croatian Academy of Arts and Science \\ Trg N. Šubića Zrinskog 11 \\ HR-10000 Zagreb \\ vladimir.markovic.hazu@gmail.com
}

\begin{abstract}
The construction of churches in the seventeenth and eighteenth centuries reflects two different architectural tastes. One is represented by the Dalmatian masters associated with the architectural tradition of their native region, and the other - defined by the standards of the contemporary Baroque style - came with foreign architects from Italy. In this paper, the author discusses the basic architectural features of churches designed by Dalmatian architects and how to define those features in terms of their style.
\end{abstract}

Key words: church, Dalmatia, seventeenth and eighteenth centuries, Dalmatian architects, style, tradition.

The construction of churches in the seventeenth and eighteenth centuries reflects two different architectural tastes. One is represented by the Dalmatian masters associated with the architectural tradition of their native region, while the other - defined by the standards of the then contemporary Baroque style - came with foreign architects from the opposite shores of the Adriatic Sea, i.e. from Italy. Both tendencies persisted as complementary but equally important values. From the perspective of social history, one architectural taste cannot be viewed as elitist and the other as populist, since both were shared by all layers of the society- from bishops and monastic orders to parishioners in small villages.

Churches designed by foreign architects are few in number. ${ }^{1}$ In the Venetian part of Dalmatia, which stretched down the Adriatic coast from Zadar all the way to the Republic of Ragusa (i.e. Dubrovnik) in the south, there are only three such structures: the Church of St. Simon in Zadar, dating to the early seventeenth century, the Chapel of the Holy Cross on the islet of Badija, which was designed by Giorgio Massari (1687-1766) a hundred years later, and the parish church at Kaštel Štafilić, also designed by "a Venetian architect" near the end of the same century. Even if this modest number is enhanced by the unconstructed designs of Vincenzo Scamozzi (1548-1616) to extend the Spilt cathedral ${ }^{2}$ and the construction of the Church of St. Nicholas in Zadar near the end of the eighteenth century, nothing changes in the chronology of scarce participation by foreign architects in the construction of churches in the territory of the Venetian Dalmatia.

As opposed to the sparse involvement by foreign architects in Venetian Dalmatia, which took place at hundred-year intervals, their churches in Dubrovnik - though equally few in number - were constructed practically simultaneously. By the end of the first decade of the eighteenth century, the cathedral was not completed as yet, but works had already commenced on the construction of two other churches: the Jesuit church and the Church of St. Blaise. Over this short time-span, Dubrovnik saw stylistic shifts which took more than a century in Venetian Dalmatia. Specifically, the Dubrovnik

\footnotetext{
${ }^{1}$ This paper does not include churches designed by engineers in the service of the Venetian Republic, who were assigned to reconstruct and build fortifications, state-owned public-purpose facilities and settlements, and to design and maintain roads in Dalmatia.
} 
cathedral follows the triple-nave Latin cross pattern, the Jesuit Church is a Late-Baroque single-nave structure, though without a dome, while the Church of St. Blaise features a medieval Venetian Greek cross set into a square layout and renovated by the elements of Late Palladian classicism. ${ }^{3}$ Despite the differences in the dynamics of stylistic shifts, the churches designed by foreign architects in Dubrovnik, as well as those in Venetian Dalmatia, have the same share in the history of sacral architecture in the seventeenth and eighteenth centuries. While they feature key elements of stylistic development, their architecture had only a minor influence on the endeavours of Dalmatian architects.

Dalmatian patrons rarely sought designs from foreign architects because their conservative understanding of architecture opposed change and the acceptance of novelties. For instance, the Dubrovnik authorities requested that their new cathedral should follow the pattern of a triple-nave Late-Renaissance structure rather than a single-nave layout, which was at the time - i.e. the latter half of the seventeenth century - already a standard solution, and not only in Roman architecture. The preference for conservative architectural solutions was also demonstrated in Split, where the authorities refused to accept Scamozzi's design to expand the cathedral. The expansion made thereafter (probably also based on a Venetian design) was smaller and simpler and, it terms of its style, more conservative.

The inconsistency between the original plans and the eventual expansion of the Split cathedral was not only a consequence of the adversities following an outbreak of the plague, but may have also been caused by the reticence that ensued from doubts about the design proposed by Scamozzi. This reticence would also emerge in other examples of collaboration between Dalmatian patrons and foreign designers. In Zadar, for instance, during the construction of the first Church of St. Simon after 1600, the decision was made to alter the designs of a Venetian architect that were accepted roughly thirty years earlier. ${ }^{4}$ The architectural order defined by Renaissance standards rooted in Classical Antiquity was broken down in an attempt to enrich the themes featured on the façade. A set of antique rows planned on the church front was rearranged to allow Corinthian columns bear an entablature with a Doric frieze, including metopes featuring images of the prophets as well as figural and ornamental forms reduced to dimensions inconsistent with the architectural frames of the openings. In this case, architectural order was abandoned in favour of narrative.

The lengthy construction of certain buildings was not specific to Dalmatia's architecture. In Dalmatia, however, this was the reason for abandoning construction projects as such, as in the case of the aforementioned Church of St. Simon in Zadar or, at least, for altering designs in order to simplify construction works. An example of the latter is Massari's Chapel of the Holy Cross, a Franciscan church on the islet of Badija. According to its design, the chapel was supposed to have a Bohemian vault, but when it was consecrated in 1762 , its nave was enclosed with a common ceiling. At that time, there may have been a lack of skilled builders who were able to construct the planned vault structure. However, the decision to replace a rounded dome-like spatial volume with a spatial box ${ }^{5}$ also shows that archetypal forms were deeply rooted in the conceptions held by the Dalmatian patrons of the time, even when their projects were entrusted to select foreign architects. The power of such a firmly embedded collective idea about the redesign of a future church was reflected in the fact

\footnotetext{
${ }^{2}$ See V. MARKOVIĆ, "Prijedlog za Vincenca Scamozzia - projekt za dogradnju splitske katedrale", Radovi Instituta za povijest umjetnosti 34, 2010, pp. 83-90.

${ }^{3}$ The Dubrovnik cathedral was designed by the Roman architect Andrea Bufalini in 1671, and the Jesuit church by Andrea Pozzo in 1699. The Church of St. Blaise was designed and constructed by the Venetian sculptor and architect Marino Groppelli from 1706 to 1715.

${ }^{4}$ L. FONDRA, Istoria delle insignia reliqia di San Simeone profeta che si venerà in Zara, a 1686 manuscript published in Zadar in 1855; V. MARKOVIĆ, "Škrinja sv. Šimuna i arhitekura u Zadru oko 1600", Peristil 48, 2004, pp. 95-108.

${ }^{5}$ The ceiling was not installed in the nave of the chapel as a provisional solution because is corners were decorated with pargets made by Monteventi, a plasterer who was, at the same time, also making sculptures on Massari's chapel altar. The ceiling was later nevertheless replaced with a vault fashioned after Massari's design.
} 
that foreign architects had a very limited influence on Dalmatian architecture as a whole. Dalmatian architects adopted only some of the architectural elements designed in a new fashion, but not the style of new spatial layouts and structural solutions proposed by foreign architects in their designs. The example of the Franciscan church in Kuna demonstrates all of the difficulties that Dalmatian architects were unable to overcome in their attempt to reproduce select elements of the Dubrovnik cathedral on their own (1709-1714).

Construction activity was very vibrant in the territory of Venetian Dalmatia during the seventeenth and, in particular, eighteenth centuries. Churches were mostly built by local masters, while altars, sculptures and altar paintings were frequently procured from Venetian artists. In terms of their style,

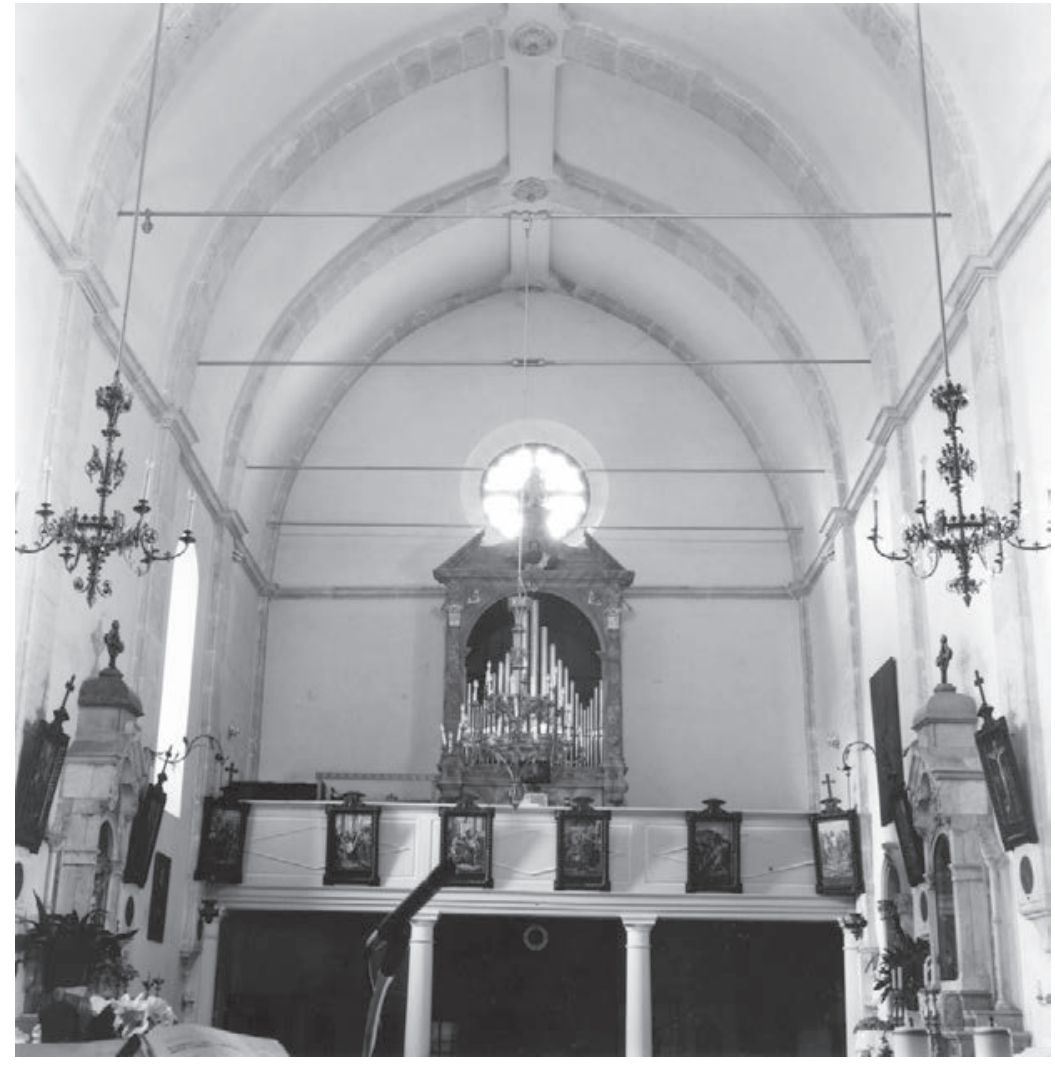

Fig. 1. Omiš, parish church, interior these works of art were not inferior to the contemporary furnishing of sacral buildings in Venice itself. It is sufficient to mention the marble altars in small community churches on the islands of Ugljan, Pašman and Brač, which - in terms of their size and tectonic structure - set the contours of the architectural identity of the area in which they are located. Differences in the origin and stylistic features of church buildings on the one hand and their inventory on the other were partly a consequence of the fact that both altars or paintings could be supplied as "finished products", whereas architecture required designs and sufficiently skilled builders that were able to carry them out. A special challenge was the construction of vaults, which - as a result - also entailed higher costs. However, technical and financial requirements were not the only obstacle. A more important reason was that the Venetian architectural culture and the Dalmatian architectural tradition were entirely different. ${ }^{6}$

The architectural culture of Venice during the seventeenth and eighteenth centuries was dictated by Andrea Palladio. Building upon earlier Renaissance theorists, who were preoccupied with Roman Antiquity, Palladio would develop the standards of the vocabulary and syntax of form as well as the measurement ratios used to draw layout plans for villas, palaces and churches. His idea of Antiquity, as presented through architecture, was accepted by the Venetian patriciate because they recognised it as a means to represent their own pedigree and the administrative system of their state, and to confirm the values to which they were committed themselves. Palladianism thus became the vehicle for and reinforcement of Venice's power as a state. Such a role of architecture and its "system" built on strictly defined rules for using classical forms went far beyond the level of Dalmatian archi-

\footnotetext{
${ }^{6}$ The differences between the Venetian and Dalmatian fine arts were easier to overcome because, given the narrative and descriptive character of figurative arts, it was easier to accept new forms in painting and sculpture than to recognise the meaning of the "abstract" and symbolic language of architecture. Its understanding requires specific historical knowledge.
} 


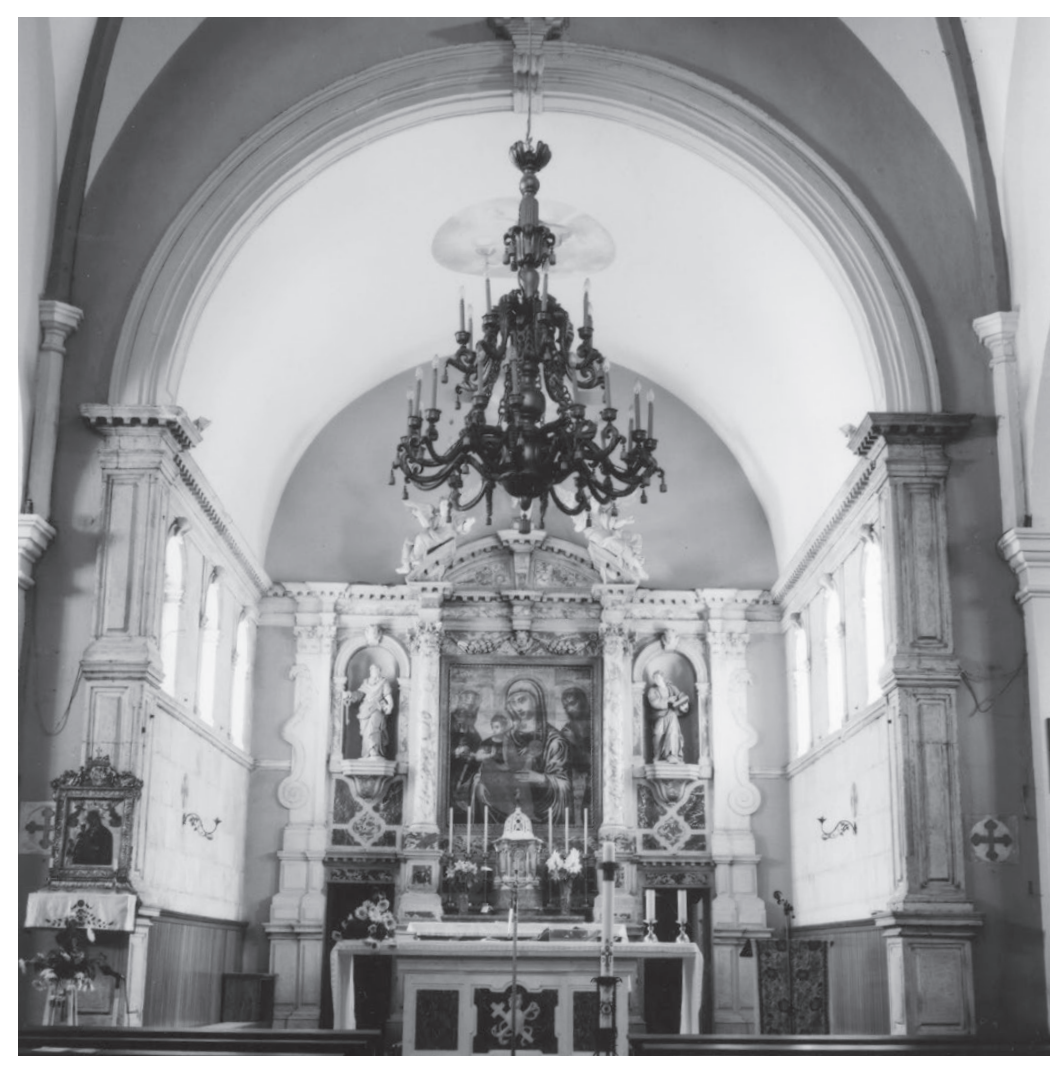

Fig. 2. Kaštel Novi, parish church, view of the apse tecture and were totally foreign to the traditional understanding of the meaning of a church building and its role in determining the historical identity of the community to which it belonged. Dalmatian society could not comprehend the conceptual basis nor was it able to identify the societal, governmental and administrative goals served by Palladianism.

The inability to understand the meaning of representative models of ancient architecture is also demonstrated by the historical fate of the façade of the Hvar cathedral. Early in the sixteenth century, a Venetian architect designed the façade by reproducing the layout plan of a classical triumphal arch. ${ }^{7}$ For the Dalmatian environment, the façade had monumental dimensions and its construction took over two hundred years, up to the mid-eighteenth century.

Numerous Dalmatian builders participated in this construction, so that it must have been noted throughout Venetian Dalmatia. Although cathedrals provided an incentive and, often, a model for the construction of churches, this façade - together with its reminiscences of Antiquity - remained totally unnoticed and left no trace on Dalmatia's later architecture.

In their activity, the inhabitants of Venetian Dalmatia were limited to their everyday lives and gatherings within religious communities and guilds which had no political or administrative influence. Individuals and their communities lived everyday lives that consisted of a series of "micro-projects" underpinned by what were already traditional values. Therefore, they recognised their historical identity in their own past and the maintenance and perpetuation of its representative content. Since they believed that this objective could also be achieved by keeping alive their memories, they often used parts of their old churches in order to build new ones, for which they would repeatedly employ select models of particularly revered local shrines, such as the cathedrals of their dioceses or Fiorentino's Early-Renaissance Chapel of St. John of $\operatorname{Trogir}^{8}$ or the parish churches in their neighbouring towns. Additionally, the model could also be provided by the existing parish church which was to be replaced by a new one. As they pursued their focus on the past, it never really mattered to which historical period the selected model belonged: the church in Podgrađe was rooted in the Romanesque era, while the Dominican church in Hvar and the naves of the Hvar cathedral, although they had barely been completed, already served as a model for triple-nave churches in the same diocese. There is also a number of other examples that suggest different time-spans between the completion of models and

\footnotetext{
${ }^{7}$ V. MARKOVIĆ, "Pročelje hvarske katedrale" in Renesansa i renesanse u umjetnosti Hrvatske, zbornik radova sa znanstvenih skupova "Dani Cvita Fiskovića" održanih 2003. i 2004., Zagreb 2008, pp. 115-138.

${ }^{8}$ V. MARKOVIĆ, "Kapela Blaženog Ivana Trogirskog Nikole Firentinca i sakralna arhitektura u Dalmaciji 300 godina poslije", Radovi Instituta za povijest umjetnosti 31, 2007, pp. 121-130.
} 
the new churches for which they were used. The temporal distance of the selected model was overridden by the significance of the ecclesiastical institution to which it belonged. The choice of models was driven by the wish to express a collective, commonly known experience. The repetition of the same model reflects the urge to perpetuate shared symbolic values and confirm the importance of the institutions that cherished them.

Dalmatian architects used the same architectural elements and structural solutions regardless of the spatial layouts of their churches. Masons made identical oval windows ornamented with volutes for both single- and multiple-nave churches. Yet, these windows, as well as a number of other masonry and building solutions, were only used in certain parts of Dalmatia. Oval windows are only found in southern and central Dalmatia, but not on churches north of Šibenik and the island of Murter. Also, seventeenth- and eighteenth-century churches have vaulted naves only in that area. The northernmost example of a vaulted nave can be found in the Church of Our

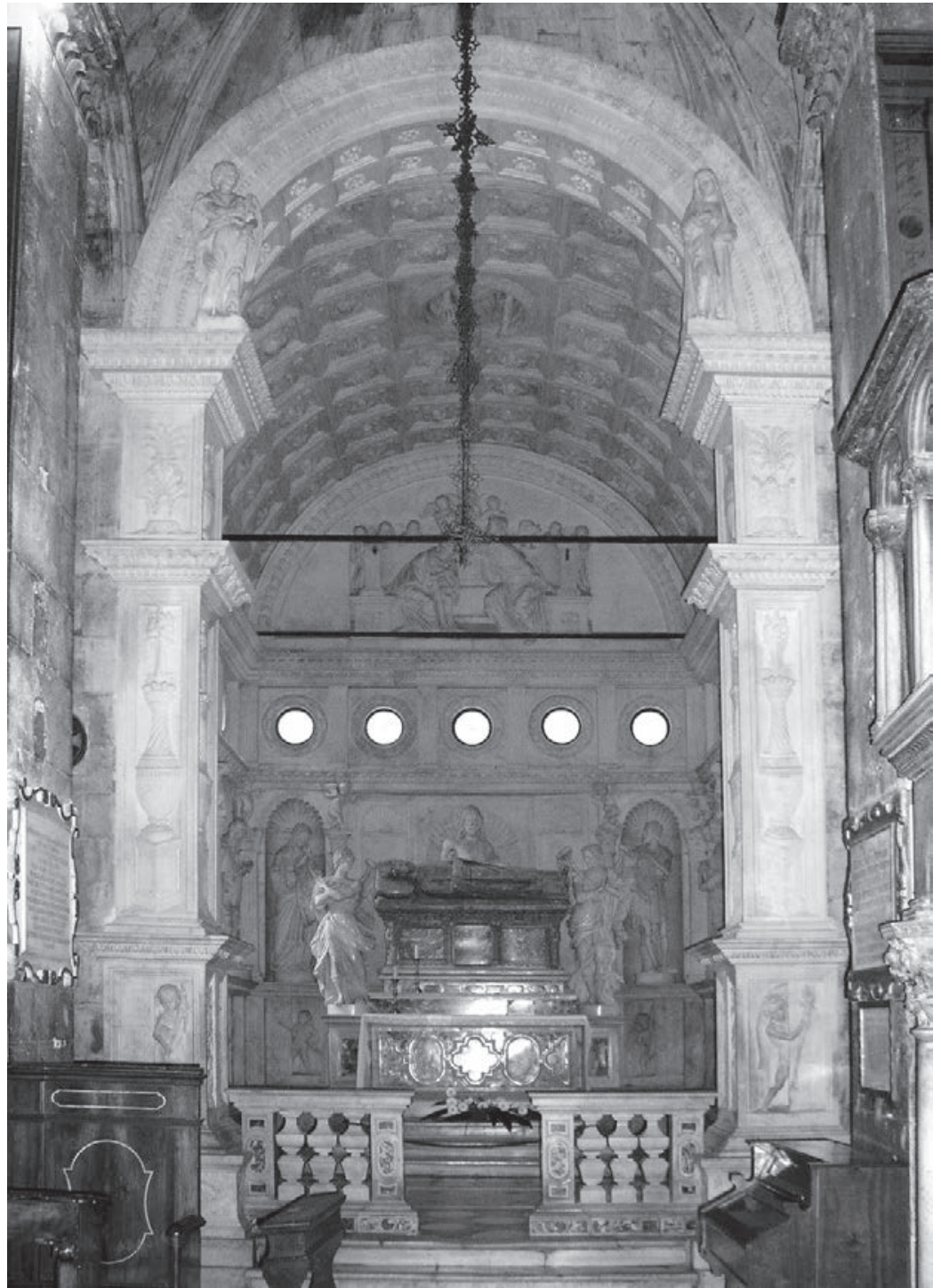

Fig. 3. Nikola Firentinac (Niccolò di Giovanni Fiorentino), Chapel of Blessed John of Trogir, cathedral, Trogir

Lady of Vrhpoljac near Šibenik. In the Zadar region, there is one vaulted church, namely, that of the Franciscan monastery in Karin, but this is an exception. This trend may have been driven by barrel-vaulted Franciscan churches in the Makarska littoral. Ties between monasteries were apparently stronger than local architectural tastes.

Other architectural forms are likewise specific only to certain micro-regions in Dalmatia. Different solutions were used for triple naves on the island of Korčula, in the Hvar Diocese and on Murter and the northern Adriatic islands. The group of churches with pointed barrel vaulting and transverse ribs around Omiš differs from other churches of the same type elsewhere in Dalmatia. The churches in the Poljica district, which were built in the eighteenth century in an effort to reproduce the form of Diocletian's Mausoleum, provide a paradigmatic example of the limited spread of a particular model. Architectural customs and building objectives were not identical in all micro-regions of Dalmatia.

Many churches designed by Dalmatian architects feature elements characteristic of different historical and stylistic periods, which raises the question of how to define them in terms of their style. The Parish Church at Gornji Humac may be considered as an example. Its nave walls are lined with engaged columns topped by consoles bearing transverse vaulting ribs, as in pre-Romanesque architecture. However, the series of transverse ribs supports a pointed barrel vault, and such a vaulting 


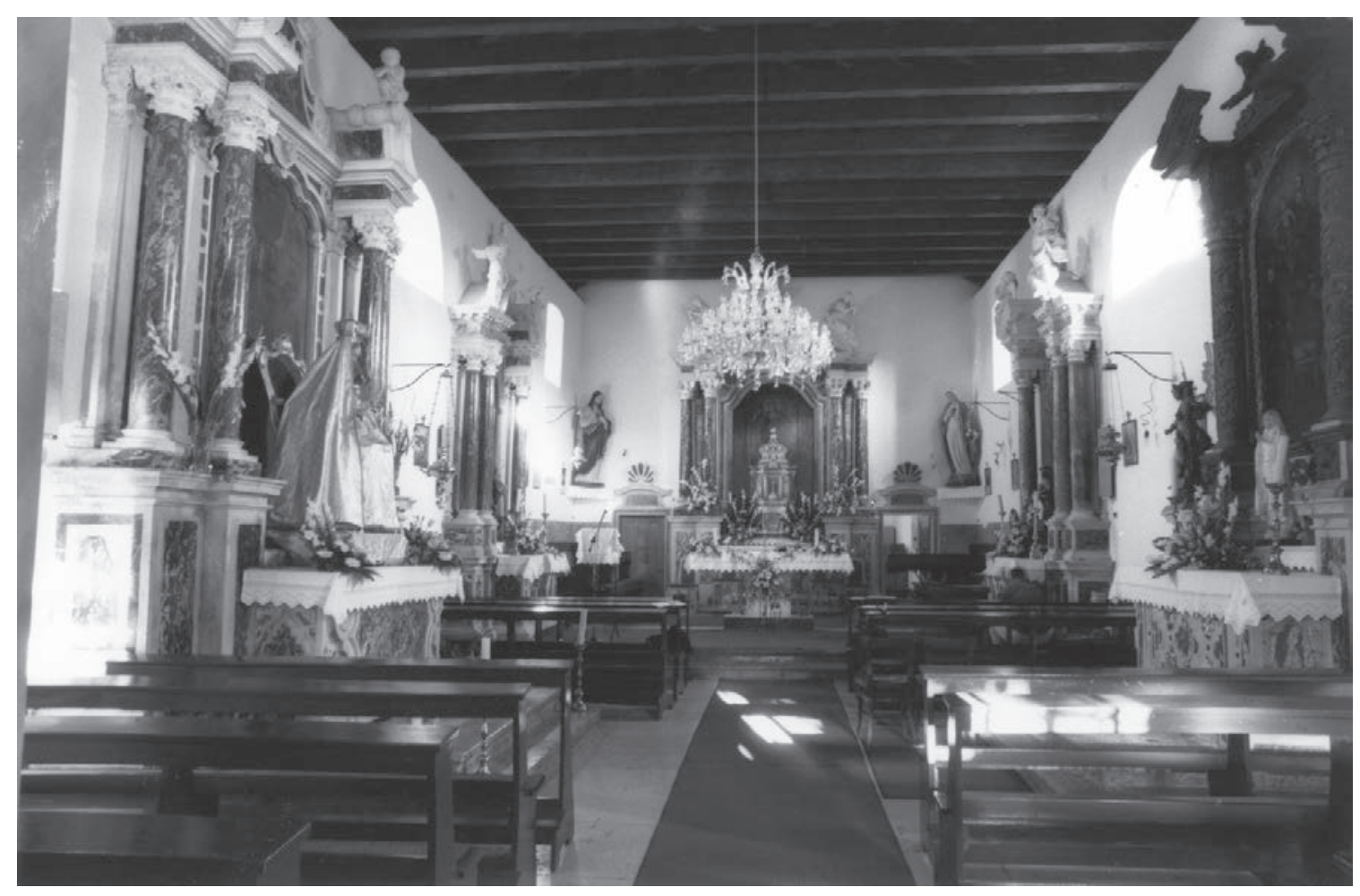

Fig. 4. Kukljica, island of Uglian, parish church, interior

structure is typical of the Late Middle Ages. Yet, by their style, the architectural sculpture, portal, oval windows and shape of the consoles bearing the transverse ribs belong to the eighteenth century - the period when the church was built. These different medieval and modest Baroque "signals" cannot be encompassed by a single stylistic concept, including that of "mixed style" - even if one were eager to use it. ${ }^{9}$ However, this "stylistic stratification" cannot equally apply to the archetypal layouts of churches because their style can hardly be defined. Specifically, simple "box-like" single-nave spaces and triple-nave spaces without transepts and domes were perpetuated over a long period, from the Middle Ages up to the nineteenth century. Then, how to invoke the historical period when they first emerged and were put in use if subsequently, in later periods, they lost their original purpose in technical and architectural as well as functional and iconographic terms? For instance, the apses of parish churches built in the eighteenth century after the model of Fiorentino's Early Renaissance Chapel of Blessed John of Trogir were given a new function and were, at the same time, impoverished in thematic, architectural, sculptural and decorative terms.

Identical architectural and structural solutions were used over long time-spans. Even when they featured clearly defined stylistic properties such as pointed barrel vaults with transverse ribs, they were perpetuated and remained unchanged over centuries. ${ }^{10}$ For example, churches with pointed barrel vaults reinforced by transverse ribs became a part of Dalmatia's architectural culture just like those vaulted with spherical barrel vaulting or those not vaulted, i.e. covered only with a ceiling. All of the

\footnotetext{
${ }^{9}$ The tendency was to encompass all differences in the style of a particular building by the concept of a transitional or mixed style. However, this would obscure the notion of style and invalidate its basic definitions because each style can be interpreted only if one uses specific interdependent and interrelated norms that build upon the experience of studying visual properties of an art of work. Trying to integrate two different styles means confronting their norms and denying their structural role. The concept of a mixed style was used to interpret works that were created on the border between two chronologically adjacent stylistic periods, most often Gothic and Renaissance. ${ }^{10}$ V. MARKOVIĆ, "Dalmatinske crkve sa šiljastim bačvastim svodom i pojasnicama - ishodišta i putovi usvajanja", Radovi Instituta za povijest umjetnosti 32, 2008, pp. 115-138.
} 
aforementioned spatial forms and architectural structures were perpetuated over many centuries with minor variations. The style of these variations can scarcely be defined.

Churches made by Dalmatian architects feature two basic architectural properties. One is determined by the layout of their space and their architectural structure. This layout was persistent and its changes were quite inert, slow, insignificant and uncharacteristic in terms of their style. The other feature is determined by their architectural sculpture. It was susceptible to changes and its style was often more clearly defined. However, the range of its forms was limited, with only a minor extension to new, stylistically characteristic patterns during the seventeenth and eighteenth centuries. Looking solely at examples which are, in terms of their style,

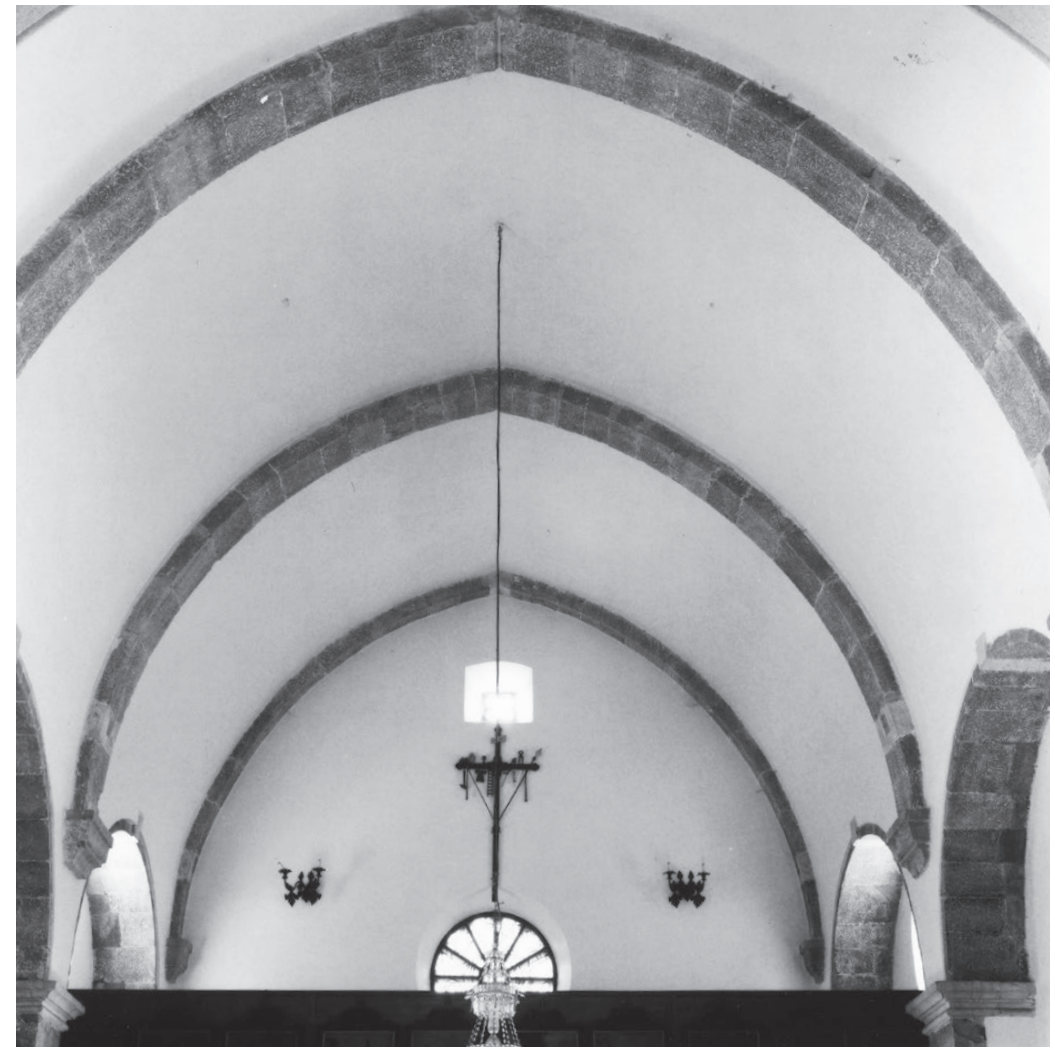

Fig. 5. Gornji Humac, island of Brač, parish church, interior the most up-to-date and closest to the standards developed in the hubs of architectural culture, it turns out that - in this respect also - the churches designed by Dalmatian architects belong to an inert or, it may appear, even a stagnant historical period. In the seventeenth century, they still used the Early-Renaissance form of capitals with flutes, ending in cymae. At the same time, they began to introduce semi-circular window openings and oval windows with frames ornamented with volutes, which were already typical for buildings in Venice a century earlier. It is even questionable whether Dalmatian architects themselves used semi-circular windows as early as the seventeenth century.

The architectural sculpture and the shape of openings - including both windows and portals on seventeenth-century churches designed by Dalmatian masters still belonged to the Renaissance period. This conclusion remains unaffected by the fact that, in the $17^{\text {th }}$ and $18^{\text {th }}$ centuries, semi-circular windows could be found on many churches in Venice and Rome, while oval windows featured on the façades of Venetian palaces. ${ }^{11}$ On those buildings, they were incorporated into a new architectural context, in which semi-circular windows could even be a sign of new stylistic changes that took place between Baroque and Late-Baroque classicism. On Dalmatian churches, their stylistic significance did not change because the context in which they were used was always the same. It was determined by the single-nave or multiple-nave archetype.

By reproducing certain novel forms, Dalmatian architects never altered the structural entity in which they would incorporate them. The basic layout remained the same. The future appearance of each church was determined by a collective experience tested over many centuries. The differences remained within the ranges of what was already known and only manifested themselves in details. As a result, the significance of seventeenth- and eighteenth-century churches built by Dalmatian mas-

${ }^{11}$ These windows are always arranged in a row at the top of the facade, just below the cornice. They have the same form as those on Dalmatian churches and their frames are also ornamented with volutes. 


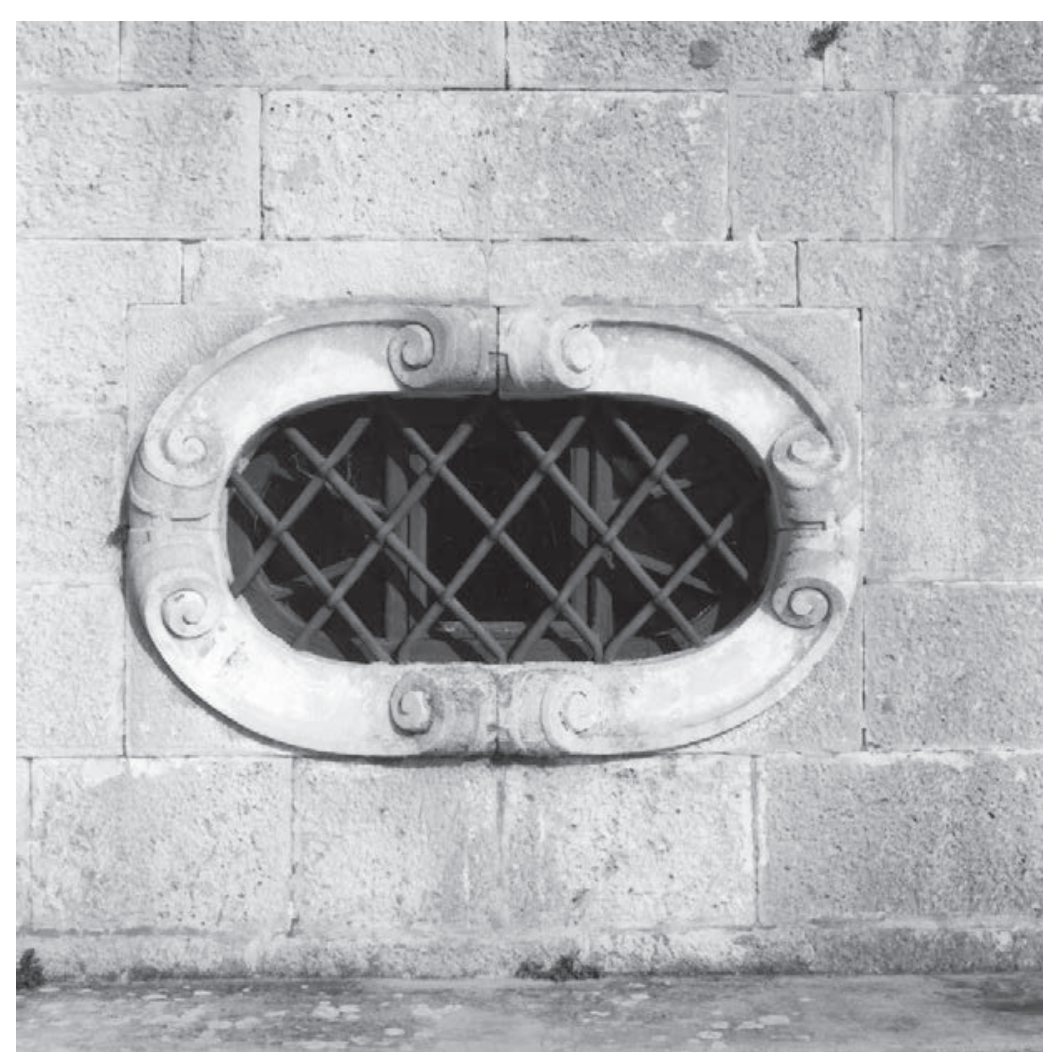

Fig. 6. Viganj, Pelješac Peninsula, Dominican Church, façade window

ters can only partly be explained by applying stylistic norms. For their historical sense can be revealed only by explaining the reasons which one and the same building features the "signals" of different historical and stylistic periods. When these past periods meet on the same building, there is no longer "earlier" and "later" - the time past seems to be flattened out.

Due to differences between churches designed by foreign and local architects, it is impossible to unequivocally define the history of sacral architecture in Dalmatia with regard to its stylistic properties and the chronology of their changes. Even if the locally designed churches with prominent features of a particular style are selected and those stylistically less characteristic are left out, the aforementioned differences will not be diminished. Allowing for minor departures, these differences persisted over both centuries and were quite prominent already from the beginning, i.e. in the first years of the seventeenth century.

Scamozzi's design for the extension of the Split cathedral and the construction of St. Simon's Church in Zadar would bring Dalmatia closer to current developments in the Venetian architecture. The very fact that Scamozzi - the most renowned Venetian (and, at the time, perhaps even European) architect - accepted the invitation of the Split Diocese already speaks volumes about the significance of that event for the history of Dalmatian architecture. With his design, Scamozzi, broadened the horizons of interest in ancient architecture, driven by Palladio's authority. Scamozzi literally cited the select elements of ancient monuments and, at the same time, developed new solutions to connect spatial units (a bridge-like choir separating the rotunda from the planned extension) and exercised greater freedom in the arrangement of ancient orders. For example, the entablature cornice is enriched by consoles only above the girders. And the unknown designer of the Church of St. Simon reproduced Palladio's method of optically connecting architectural components arranged by the depth of space in order to accentuate the scenic values of architecture. In this way, he approached the principles of designing a new, Baroque style.

Both designs considerably influenced developments in Venetian architecture of that time. Yet, they would have no impact on the traditional concepts of Dalmatian architects, either in terms of arousing their interest in Classical architecture or drawing their attention to scenic value in the design of architectural space.

Churches designed by Dalmatian architects at the same time, i.e. in the first half of the seventeenth century, were, in terms of their style, much more conservative. The parish church in Omiš and the Dominican church in Hvar may serve as two representative examples. The spatial layout and architectural structure of the church in Omiš are still medieval. The structure of its pointed barrel vault with transverse ribs in its nave is Romanesque, while its architectural elements, windows, portals, consoles and capitals are the only items that fit into the vocabulary of Early-Renaissance architec- 
ture (The main portal belongs to a later stylistic period due to ornamental motives typical for southern Italian Mannerism). The construction of the Dominican Church was completed roughly ten years after that of the church in Omiš (before 1611), but its architecture reflects no medieval vestiges. With its central nave probably closed with a ceiling (it was definitely not vaulted, although the church is now dilapidated) and its columns separated from the lateral naves, its chancel vaulted with a domelike structure and its Early Renaissance architectural sculpture, it is stylistically similar to Codussi's San Michele in Isola. However, the portal of the Dominican Church already contains the elements of Renaissance classicism. It is constructed like an aedicule, with half-columns, an entablature and a gable with a

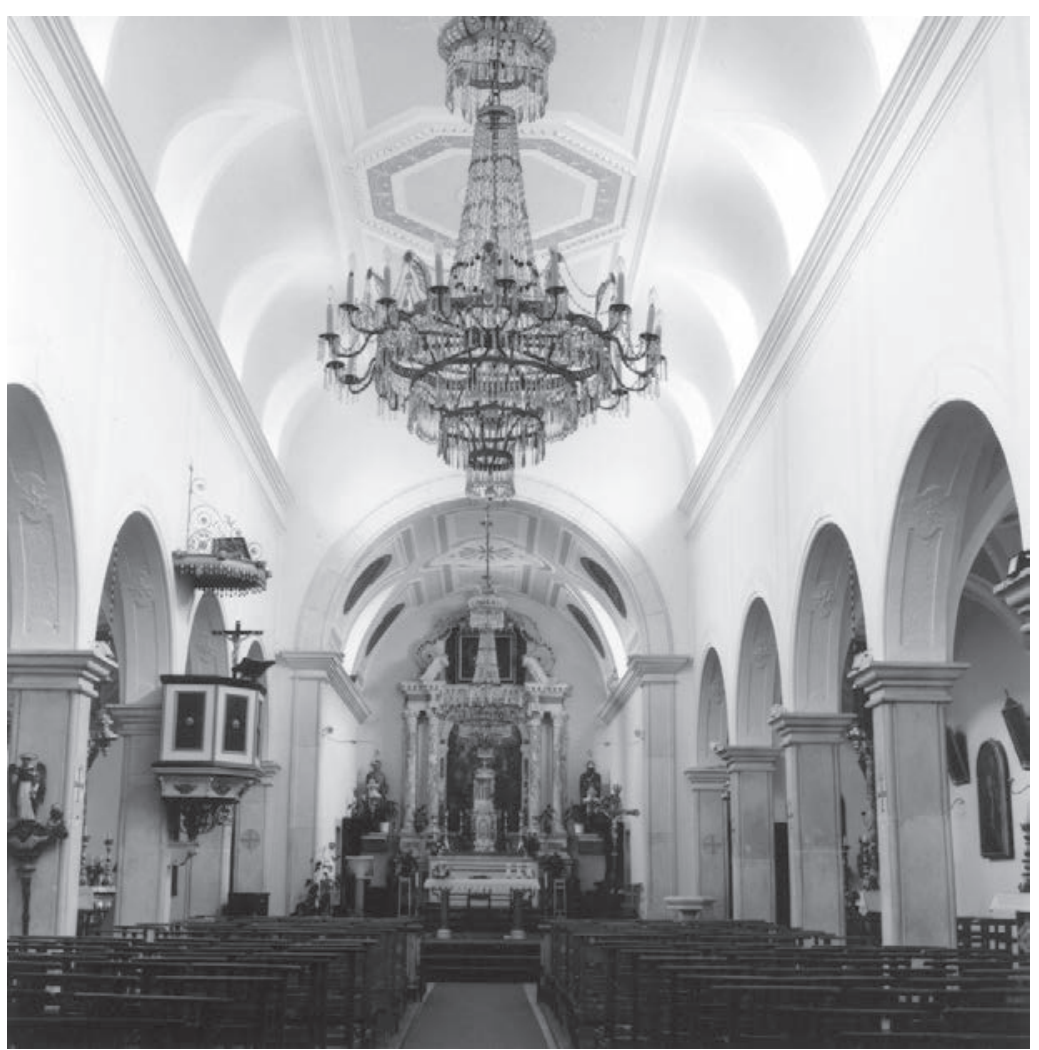

Fig. 7. Supetar, island of Brač, parish church, interior cut lintel.

The second half of the seventeenth century also remained in the "shadow" of the Renaissance. The construction of the parish church in Stari Grad under a new design continued, while the equally lengthy construction project to build the naves of the Hvar cathedral commenced. In both churches, as well as that of the Hvar Dominicans, the central nave was closed with a ceiling, while the lateral nave bays were vaulted. The parish church in Stari Grad even has an equally vaulted chancel covered with a domelike structure. Only the shape of the windows - oval in the central and semi-circular in the lateral naves - suggests the adoption of architectural elements that came into use in Venice in the $16^{\text {th }}$ century.

At the same time, i.e. in the latter half of the seventeenth century, construction works were underway on the cathedral in Dubrovnik. Its spatial layout also followed Renaissance patterns (in keeping with the conservative taste of Dubrovnik's patrons) but, as opposed to the simple triple-nave design of the churches on the island of Hvar, the Dubrovnik cathedral features a complex spatial arrangement with a transept and a dome, with its interior walls and façades rendered in a complex system of mural sculpture. Half-columns, pilasters and entablatures, including attics, represented the abundance of sculptural elements inherited by Baroque architecture from Renaissance classicism.

Differences in the style of churches designed by foreign and Dalmatian architects were especially pronounced at the beginning of the eighteenth century. The Jesuit church by A. Pozzo (designed in 1699) and the Church of St. Blaise by Groppelli (designed in 1706) as well as Massari's Chapel of the Holy Cross on Badija (designed in 1723) were dictated by Late-Baroque stylistic tendencies. Their architecture relied on past architectural traditions (leaving out a dome on the Jesuit church and Groppelli's revival of a Greek cross inscribed within a square, employing Palladian classicism), but developed - in a novel manner - a scenically designed spatial depth bordered by softly articulated walls. (The nave of the Jesuit church scenically ends in a painted apse, while the Chapel of the Holy Cross features a dark altar immersed into its own shadow, standing in front of a light and gently ornamented wall. 
At the same time, Dalmatian masters remained firmly bound to the conservative local tradition. Their triple-nave parish churches on the island of Brač were designed just as traditionally as the seventeenth-century churches on Hvar. Indeed, the parish church in Supetar (1729-1733) was originally supposed to have vaults not only above its central nave, but also above its lateral naves - just like medieval basilicas. The late construction of churches on Brač (leaving out the design of frames for certain openings and other sculptural details) is reflected only in rounded corners between their central nave ceilings and walls which are cut by diagonal ribs above window openings. This method for closing central naves was widely used along the Croatian coast of the Adriatic and, at the time, it was almost regularly applied to vault the main naves of medieval cathedrals and large basilicas in Zadar, Rab, Osor and Pag.

Equal ties to the past are also shown by churches with pointed barrel vaults and transverse ribs, as well as simpler single-nave "spatial boxes", where only the frames of their openings demonstrate that, in terms of style, they belong to the period after 1600. It would be an overstatement to say that, in the eighteenth century, single-nave, tall, flat-ceiling churches were built as a consequence of new Baroque concepts of structural proportions and the wish to accentuate the vertical ascent of the space. This was due rather to functional reasons driven by the need to place altars next to lateral walls. Specifically, Baroque altars were much larger than those from earlier periods, and were dedicated to the adoration of new saints and liturgical rites introduced by the Counter Reformation. The same reasons led to an increase in the dimensions of apses (the parish churches in Sutivan and Zlarin, the Church of Our Lady outside of the city walls in Šibenik). Nevertheless, there are some eighteenth-century examples in which new proportions may be explained by changes in style. In certain churches, the apses are the same width as the naves and have a semi-circular base. The cornice which continues from the nave into the apse shows that the intention was to connect both spaces, rather than only make them equal in size, which may be deemed to reflect a push for Baroque integration and a closer connection between the individual spatial segments of churches. Another Baroque feature could be the positioning of windows, which were raised to the level of the vaulting structure. However, in rural single-nave churches, there are no diagonal ribs above such windows raised to the level of their vaults. Their vaulting remained a heavy continuous structure. Speaking about of any fully accomplished stylistic intent is precluded by the lack of other signs of change in their archetypal layout. ${ }^{12}$

The archetypal spatial layouts used by Dalmatian masters in the seventeenth and eighteenth centuries did not always have the same share in the stylistic definition of their churches. In the seventeenth century, when they were still preoccupied by the elements of Renaissance architecture - architectural sculpture in particular - simple basilical and single-nave prismatic spaces did not contradict Renaissance architectural practices. In his treatise, even Alberti recommends the square as a desirable floor plan for churches, as well as the square and a half, square and a third and double square. ${ }^{13}$ Although Alberti maintained that basilicas were inappropriate due to their secular function in Antiquity, elongated basilical structures, often even without domes and transepts, were still built not only in Dalmatia but elsewhere, too, because they were appropriate for congregational gatherings. However, this is also where this similarity in principle between Dalmatian archetypal and Renaissance spatial layouts ends. The principles of Renaissance composition - where architectural sculpture breaks wall surfaces into carefully dimensioned sections in order to merge spatial segments into a harmonious entity defined by mathematical proportions - were not implemented in Dalmatian churches. The walls of churches designed by Dalmatian architects are bare. They are not elaborated by architectu-

\footnotetext{
${ }^{12}$ The fact that the apse is equal to, but narrower and lower than the nave is a stylistic sign only in the context of the Dalmatian architectural tradition, because the same proportion between the nave and the apse may also be found in earlier stylistic periods.

${ }^{13}$ In his treatise De re aedificatoria (around 1450); English translation: On the Art of Building, USA, 1988, pp. 189-200.
} 
ral sculpture, which is not a consequence of leaving out or reducing some more complex design processes, but has a totally different background. In this way, Dalmatian masters were building upon the architectural tradition of their own native region (Such a simply constructed church could be defined in terms of its style only once it was "furnished" with architectural sculpture).

In the eighteenth century, such archetypal spatial layouts could not be "adjusted" to the principles of the Baroque style, whereby the space of a church was determined by its dynamic or scenic values. Such an approach was precluded by the traditional triple-nave structure. However, simple "box-like" structures like those in Dalmatia were also constructed in Venetian sacral architecture at the time, but their stylistic identity was dictated by Palladian Late Baroque classicism. Classical architectural sculpture, columns, semi-columns, pilasters and beams, and even façades formed like the frontal side of a temple, endowed a simple prismatic church building, both its interior and exterior, with the structural strength and austerity that rest directly on Antiquity and its perennial values. Dalmatian churches, constructed as simple roofed boxes, cannot be considered a result of efforts to simplify Venetian models, but to perpetuate a "Dalmatian archetype" that was created ages before. Its stylistically undefined features that contrasted with Baroque concepts of space could not be affected by architectural sculpture because it was mostly limited to the frames of openings.

Stylistic norms and regional features are complementary forces that define the churches designed by Dalmatian architects. In the eighteenth century, regional characteristics prevailed over stylistic features. However, that notion of regional includes not only the archetypal layout of space, but also all those structural, ornamental and decorative patterns which were, in the previous centuries, already part of Dalmatia's architectural legacy. The notion of regional encompasses the façade oculi, bellcotes, specific masonry procedures, such as, for instance, opening construction methods, ornaments, and all architectural elements that differ by their periodic and stylistic origins. Where such different elements, including those that are novel and recently adopted (which, in this case, belong to the Renaissance and Baroque), display pronounced stylistic features, one may speak of stylistic syncretism.

The aforementioned features of Dalmatian churches were not isolated in the history of seventeenthand eighteenth-century architecture. Similar relationships between architectural tradition and new styles were also typical of certain other regions outside of the major hubs. They were also characterised by the long persistence and perpetuation of specific spatial layouts, similar procedures for reproducing what had already been adopted and adopting what was new, as well as the directions of change that would follow. However, the differences between the regional architectural tradition, entrenched so deeply in the past, and the architecture designed and built by foreign masters for Dalmatian patrons have no match whatsoever in terms of their persistence and longevity, at least within that part of the Adriatic and Mediterranean area to which the seventeenth- and eighteenth-century Croatian architecture created in Dalmatia belongs. 


\section{CRKVE DALMATINSKIH GRADITEUA 17. I 18. STOUEĆA}

U izgradnji crkava 17. i 18. stoljeća u Dalmaciji očituju se dva različita arhitektonska ukusa. Jedan zastupaju dalmatinski majstori vezani uz graditeljsku prošlost svog zavičaja a drugi, određen normama suvremenog baroknog stila, donose strani arhitekti sa susjedne obale Jadrana, iz Italije. Oba usmjerenja traju kao komplementarne ali jednako važne vrijednosti. S obzirom da oba arhitektonska ukusa dijele svi slojevi društva, od biskupa i svećeničkih redova, do župljana po malim mjestima, ne može se, gledajući sa stajališta socijalne povijesti, jedan ukus smatrati elitnim a drugi pučkim.

Dalmatinski su naručitelji rijetko tražili projekte stranih arhitekata, jer njihova su se konzervativna shvaćanja arhitekture opirala promjenama i usvajanju novog. Venecijanska arhitektonska kultura i dalmatinska graditeljska tradicija bile posve različite.

Arhitektonsku kulturu Venecije 17. i 18. stoljeća odredio je Andrea Palladio.

Njegovu je predodžbu antike, predočenu arhitekturom prihvatio venecijanski patricijat, jer je u njoj prepoznao sredstvo reprezentacije vlastitog poretka i upravnog uređenja države, te našao potvrdu vrijednosti za koje se i sam zalagao. Paladijanizam tako postaje sredstvo i potvrda venecijanske državne moći. Takva uloga arhitekture i njezin "sustav" izgrađen na strogo određenim pravilima korištenja antičkih oblika, visoko nadilaze razinu dalmatinskog graditeljstva, i bili su posve strani uvriježenom shvaćanju smisla crkvene građevine i njezine uloge u određenju povijesnog identiteta zajednice kojoj ona pripada. Dalmatinsko društvo nije moglo razumjeti idejne osnove, niti prepoznati društvene i državno-upravne ciljeve kojima je paladijanizam služio.

Stanovništvo venecijanske Dalmacije bilo je ograničeno životom svakodnevice i okupljanjem u vjerske i cehovske udruge koje nisu imale političko-upravni utjecaj. Pojedinci i njihove zajednice žive svoju svakodnevicu sastavljenu od niza "mikro projekata", oslonjenih na već ustaljene vrijednosti. Stoga su svoj povijesni identitet prepoznavali u vlastitoj prošlosti i održavanju i ponavljanju njezinih reprezentativnih sadržaja. Smatrali su da će tu namjeru ostvariti i čuvanjem sjećanja, tako da su često dijelove stare crkve koristili pri gradnji nove, za koju bi opet koristili odabrane predloške osobito štovanih domaćih svetišta, poput katedrala njihovih biskupija, ili Firentinčeve ranorenesansne kapele sv. Ivana Trogirskog, pa župne crkve iz nekog susjednog mjesta. Za tu okrenutost prošlosti nije bilo tako važno iz kojeg je povijesnog razdoblja odabrani predložak. Vremensku udaljenost od izabranog predloška prevladava značaj crkvene ustanove kojoj taj predložak pripada. Izbor predložaka potaknut je željom da se izrazi kolektivno, svima poznato iskustvo. Ponavljanje istog predloška izraz je namjere da se nastave zajedničke simboličke vrijednosti i potvrdi važnost ustanova koje ih njeguju.

Mnoge crkve dalmatinskih graditelja sadrže elemente koji su karakteristični za različita povijesnostilska razdoblja, pa se postavlja pitanje kako te crkve stilski odrediti. Različite srednjovjekovne, renesansne i skromne „signale“ baroka nije moguće obuhvatiti jednim stilskim pojmom, pa niti onim "mješovitog stila" - ako bismo ga i htjeli upotrijebiti. Ali tom „stilskom slojevitošću“ ne mogu se jednako obuhvatiti i arhetipske nacrtne sheme crkava, jer je te nacrtne sheme teško stilski odrediti. Naime, poput „kutija“ jednostavni jednobrodni prostori i trobrodni bez transepta i kupole ponavljaju se dugo, od srednjega vijeka pa sve do 19. stoljeća. Kako se pozvati na povijesno vrijeme kada se prvi puta javljaju i koriste, ako su potom, u kasnijim razdobljima, u tehničko-graditeljskom pogledu i u upotrebnom i ikonografskom pogledu izgubile svoj izvorni smisao. Podsjetimo se na apside župnih crkava koje su u 18. stoljeću građene po uzorku ranorenesansne Firentinčeve kapele bl. Ivana Trogirskog. One su dobile novu funkciju i istodobno su tematski, arhitektonski i plastički-dekorativno osiromašene.

Crkve dalmatinskih graditelja sadrže dvije temeljne arhitektonske osobine. Jednu određuje nacrtna shema prostora i njegova građevna konstrukcija. Ta shema je trajna i mijenja se vrlo usporeno, neznatno i stilski nekarakteristično. Drugu njihovu osobinu određuje arhitektonska plastika. Ona je podložna promjenama i često je stilski jasnije određena. Međutim, raspon njezinih oblika je skučen, i tijekom 17. i 18. stoljeća neznatno se proširuje na novi, stilski karakterističan način. Ako se odaberu samo oni primjeri koji su u stilskom pogledu najažurniji i najbliži standardima u razvijenim središtima arhitek- 
tonske kulture, pokazat će se da crkve dalmatinskih majstora i u tom pogledu pripadaju usporenom povijesnom vremenu. Zato se i značenje crkava 17. i 18. stoljeća, koje grade dalmatinski majstori, može tek djelomično objasniti primjenom stilskih normi. Jer njihov se povijesni smisao otkriva tek kad se protumače razlozi zbog kojih su na istoj građevini prisutni „signali“ različitih povijesno-stilskih razdoblja.

Zbog razlika između crkava stranih arhitekata i domaćih graditelja nije moguće jednoznačno odrediti niti povijest sakralne arhitekture u Dalmaciji u pogledu stilskih osobina i slijeda njihovih promjena. Ako se čak odaberu crkve domaćih graditelja s izraženim znakovima stila i izostave sve one stilski manje karakteristične neće se umanjiti spomenute razlike.

Arhetipske sheme prostora koje u 17. i 18. stojeću koriste dalmatinski majstori nisu uvijek imale isti udio u stilskom određenju njihovih crkava. U 17. stoljeću, kada su bili još zaokupljeni temama renesansne arhitekture, uglavnom arhitektonskom plastikom, jednostavni bazilikalni i jednobrodni prizmatični prostori nisu u suprotnosti s renesansnom graditeljskom praksom. Ali kod njih nisu provedena načela renesansne kompozicije, gdje arhitektonska plastika dijeli zidne površine u pomno odmjerene veličine da bi se prostorni dijelovi povezali u harmoničnu matematičkim omjerima određenu cjelinu. Zidovi crkava dalmatinskih graditelja su goli, nisu raščlanjeni arhitektonskom plastikom, što nije posljedica izostavljanja i redukcije nekog složenijeg postupka oblikovanja, nego je njihovo porijeklo drugačije. Dalmatinski majstori tako nastavljaju graditeljsku tradiciju vlastitog zavičaja (Tek kad bi se tako jednostavno građena crkva „opremila“ arhitektonskom plastikom izraženih stilskih osobina ona bi dobila stilsko određenje).

U 18. stoljeću iste arhetipske prostorne sheme nije se moglo „prilagoditi" načelima baroknog stila po kojima prostor crkve određuju njegove dinamičke ili scenične vrijednosti. Tradicionalna trobrodnost isključivala je takove mogućnosti. Međutim, u venecijanskoj sakralnoj arhitekturi, u to se vrijeme grade također jednostavni jednobrodni „kutijasti“ prostori kao i u Dalmaciji, ali njihov stilski identitet bio je određen paladijevskim kasnobaroknim klasicizmom. Klasicistička arhitektonska plastika, stupovi, polustupovi, pilastri i gređe, pa pročelje oblikovano poput čeone strane hrama davali su jednostavnoj prizmatičnoj zgradi crkve, njezinoj unutrašnjosti i vanjštini, građevnu snagu i ozbiljnost koja se neposredno oslanja na antiku i njezine trajne vrijednosti. Dalmatinske crkve građene poput jednostavnih natkrovljenih kutija ne mogu se smatrati rezultatom pojednostavnjenja venecijanskih predložaka, nego nastavljanjem davno ranije formiranog "dalmatinskog arhetipa“. Njegova stilski neodređena i baroknim poimanjima prostora suprotna svojstva nije mogla promijeniti arhitektonska plastika jer je svedena uglavnom na okvire otvora.

Stilske norme i regionalne osobine komplementarne su snage koje određuju crkve dalmatinskih graditelja. U 18. stoljeću regionalne osobine jače su od stilskih značajki. Ali taj pojam regionalnog uključuje ne samo arhetipsku shemu prostora nego i sve one plastičke i ornamentalno-dekorativne oblike koji su u prethodnim stoljećima već pripadali graditeljskom nasljeđu Dalmacije. Pročelni okulusi, preslice, karakteristični zidarski postupci, na primjer način izgradnje otvora, ornamentika, svi po vremenskom i stilskom podrijetlu različiti dijelovi građevine obuhvaćeni su pojmom regionalnog. Kada ti različiti dijelovi, uključujući i one nove, tek usvojene imaju naglašene stilske osobine može se govoriti o stilskom sinkretizmu.

Navedene osobine dalmatinskih crkava nisu usamljene u povijesti arhitekture 17. i 18. stoljeća. Slični odnosi između lokalne arhitektonske prošlosti i novog stila karakteristični su i za neke druge regije izvan velikih središta. I za njih je karakteristično dugo trajanje i ponavljanje pojedinih prostornih shema, slični su postupci ponavljanja ranije usvojenog i usvajanja novog kao i putovi promjena koji će se potom zbivati. Ali nigdje, barem u onom dijelu jadranskog i sredozemnog prostora kojemu pripada hrvatska arhitektura 17. i 18. stoljeća ostvarena u Dalmaciji, neće se toliko uporno i dugotrajno održati razlike između regionalne graditeljske tradicije koja seže tako duboko u prošlost, i one arhitekture koju za dalmatinske naručioce projektiraju i grade strani arhitekti.

Ključne riječi: Crkva, Dalmacija, 17. i 18. stoljeće, dalmatinski arhitekti, stil, tradicija 